\title{
Local level sustainability planning for livelihoods: A Cambodian experience
}

\author{
Melissa Marschke and Fikret Berkes \\ Natural Resources Institute, University of Manitoba, Winnipeg, Canada \\ Key words: Livelihoods, sustainability, resource management, community, Cambodia
}

\begin{abstract}
SUMMARY
How do Cambodian villagers perceive sustainability and what do they do 'on the ground'? Looking at sustainability issues through the lens of two local resource management committees, and using a triangulation of social science research methods, this paper examines the roles and responsibilities of these groups and how they grapple with resource degradation and related activities. The committees have experimented with a range of resource management strategies, from creating fishing sanctuaries to resolving fishing gear theft. The results indicate that one reason villagers are willing to engage in community-based management is when they believe that they can improve livelihoods within their community. Community-based management is being carried out in the absence of formal legislation; it is recognized through government policy and administrative approvals. In this regard, local-level support and leadership has been key, and the current arrangement has created the political space for experimentation and learning.
\end{abstract}

\section{INTRODUCTION}

The concept of sustainability is increasingly being applied to specific social-ecological processes such as urbanization, renewable energy development and ecosystem-based management (Sneddon 2000). Sustainability is seen, not as a fixed ideal state or an end point, but as a process of attempting to improve the management of systems through learning, understanding and better use of knowledge (Wilkinson and Cary 2002; Berkes et al. 2003). Often, the starting point of analysis is not some degree of sustainability, because this cannot be observed, given space and time scale complexities (Ludwig et al. 1993). Rather, a more promising starting point is unsustainability - which can be observed. What is known to be unsustainable may evolve with social learning (Lee 1993) and self-organization (Ekstrand and Ray 2001), making the process of sustainability dynamic rather than static.

The approach of using unsustainability as the starting point has been used, among others, to analyze a case of acidified and disease-impacted crayfish lakes in Sweden (Olsson and Folke 2001), and a case in coastal Cambodia in which the evolution of adaptive co-management in a degraded mangrove ecosystem was traced (Marschke and Nong 2003). Adaptive co-management helps operationalize the dynamics of sustainability because it combines: (1) elements of adaptive management or learning-by-doing (Holling 1978), and (2) elements of co-management, or the sharing of management power and responsibility between government agencies and local communities (Olsson et al. 2004). In practice, resource management is

Correspondence: M. Marschke, Natural Resources Institute, University of Manitoba, 70 Dysart Road, Winnipeg, Manitoba R3T 2N2, Canada. Email: mjmarschkeca@yahoo.com or berkes@cc.umanitoba.com 
almost never purely government level or purely community-based (Pomeroy and Berkes 1997). Virtually all resource management systems have some external linkages and drivers at different scales (Berkes 2002).

Nevertheless, the involvement of local communities with learning and shared management, the bottom-up (rather than top-down) view of sustainability, is a key consideration. What sustainability looks like to resource users themselves is important because sustainability policies need to be grounded, building on the knowledge and practices of rural people and resource-based communities throughout the world (LaRochelle and Berkes 2003; Bingeman et al 2004). Kates et al. (2001) have argued that a new 'sustainability science' requires place-based models, and that understanding the dynamic interaction between environment and society requires cases situated in particular places. This is consistent with the 'Johannesburg Memo' which has tackled the integration of environment and development agendas, giving priority to environmental fairness, equity, livelihood and poverty alleviation concerns (Sachs 2002).

In this regard, the consideration of livelihoods is particularly important because sustainability is perceived strongly in the context of livelihoods among resource-dependent rural people. Sachs (2002) points out that equity and livelihood considerations bring out the question of power and access rights. Blaikie (1995) emphasizes the political dimensions of rights over resources: those seeking to understand environment-development problems need to explore multiple linkages. Sustainability, therefore, has become 'a vital element in the discourse of researchers trying to explain the relations between economy, society and environment, and to influence these' (Adams 2001: 5). Understanding the environmental, economic and political factors that enhance livelihood options or, alternatively, create poverty lies at the heart of sustainability.

A livelihood comprises the capabilities, assets or resources, entitlements and activities required for living (Scoones 1998). The definition of sustainable livelihoods was provided by Chambers and Conway (1992:6): 'a livelihood is sustainable when it can cope with and recover from stresses and shocks, maintain or enhance its capabilities, assets and entitlements, while not undermining the natural resource base.' Sustainability centres the discussion on 'the actual strategies that people employ to attain and protect livelihoods rather than on national development strategies far removed from people's lived experiences' (Sneddon 2000: 535). Such an analysis includes communities that undertake environmental actions to ensure access to and control over critical resources. This article, therefore, seeks to bring to light various 'on the ground' activities of two Cambodian community-level resource management committees grappling with sustainability.

The focus of this article is how those villagers involved with resource management committees perceive sustainability and what they do 'on the ground' once they are organized and have their management plans recognized through the signature of government authorities. We provide an analysis of two resource management committees, highlighting how community-based management can unfold at the local level and why villagers are participating in such activities. Through the lens of these resource management committees, we look at livelihood issues as motivating actions towards sustainability. We investigate the strategies undertaken by these committees and their ability to approach sustainability issues at the local level.

\section{STUDY AREA AND METHODS}

Field research took place in two rural Cambodian fishing communities, one coastal and one freshwater, over a 16-month period (Figure 1). Koh Sralao is a coastal village of 297 households that became actively involved in community-based management as their resources became depleted. Kompong Phluk is a commune (a commune is several villages combined as an administrative unit) of 434 households on the Tonle Sap Lake that has been practicing community-based management since the 1940s, perhaps one of the oldest examples of resource management (forestry and fisheries) known in the region (Evans 2002).

Table 1 provides some of the key characteristics of each study area. Both communities are dependent on fishery resources for their livelihood. In Koh Sralao, $75 \%$ of households surveyed were involved in fishing activities; in Kompong Phluk, the figure was even higher at $86 \%$. The two communities differ in terms of homogeneity and stability. Koh Sralao includes many households that were 
displaced by internal conflicts and economic disasters in other provinces, whereas the household composition in Kompong Phluk has been relatively stable. Less than $40 \%$ of households in Koh Sralao have lived in the community for ten years or more. Most households have learned to harvest various resources, after other income generating activities, such as charcoal production and shrimp farming, collapsed (Marschke and Nong 2003). This differs significantly from Kompong Phluk where almost all of the people have continued to live in the community (returning after the Khmer Rouge) and intend to stay. In Koh Sralao, by contrast, nearly half of the households intend to move to other opportunities elsewhere.

Both field sites have had support from development agencies; this support has been more of a technical nature than financial. Although not within the scope of this paper, the role of government partners and donor agencies in facilitating a community-based management process in Cambodia deserves further analysis. In Koh Sralao, the Participatory Management of Mangrove Resources (PMMR) research team has worked with villagers on community-based management issues since 1998. In Kompong Phluk, the project team of the Participatory Natural Resource Management in the Tonle Sap Region project team has worked with villagers on resource management issues since the mid-1990s. Both areas are acknowledged as success stories for community-based management; other communities are not necessarily as well organized, interested or active (Evans 2002; Marschke and Nong 2003).

Qualitative and quantitative methods were used for data collection and analysis, spanning the individual, household and community level. Participatory research methods (Chambers 1997; IIRR 1998) included: (a) two community workshops focusing on notions of livelihood and sustainability; (b) focus group sessions with both resource management committees carried out over 16 months; and (c) a longitudinal study of household level coping and adapting strategies, over 16 months, with five households in each community. Quantitative methods included a livelihood compositions and dynamics survey with 148 households, representing $20 \%$ of the households in each community. Research findings were supplemented, and triangulated, with project reports and documents from projects working in both field sites.

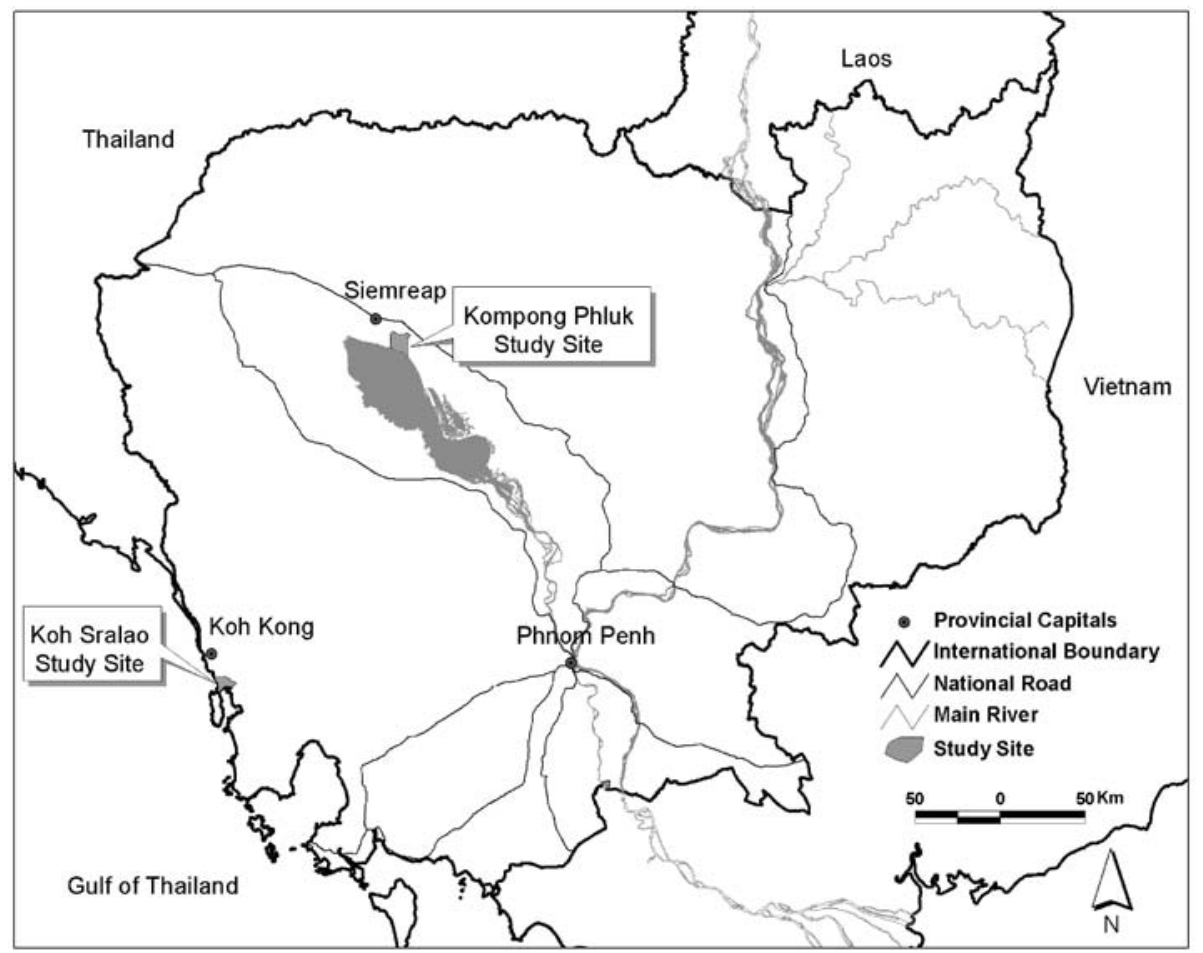

Figure 1 The two study sites, Koh Sralao and Kompong Phluk, Cambodia 
Table 1 Details of the two study areas

\begin{tabular}{lcc}
\hline & $\begin{array}{c}\text { Koh } \\
\text { Sralao }\end{array}$ & $\begin{array}{c}\text { Kompong } \\
\text { Phluk }\end{array}$ \\
\hline No. households (hhs) in area & 297 & 434 \\
Percent of hhs surveyed & 20 & 20 \\
Percent hhs involved in fishing & 75 & 86 \\
Percent hhs living in area for & 40 & 92 \\
$\quad>10$ yrs & & \\
Percent hhs intending to stay in & 57 & 85 \\
$\quad$ the area & & \\
\hline
\end{tabular}

\section{COMMUNITY-BASED MANAGEMENT IN CAMBODIA}

I did not really think that resource management would improve our livelihoods. But, we are now able to solve some problems... We feel that our resources are improving a little bit as a result of our work (Resource Management Committee member, pers. comm.; Koh Sralao 2003).

After the disastrous Khmer Rouge regime of the late $1970 \mathrm{~s}$ and the Vietnamese occupation of the 1980s, reorganization has been occurring in Cambodia in a number of spheres of life. According to Godfrey et al. (2002), Cambodia can be characterized as both a post-conflict society and a transition economy. These changes have resulted in an eclectic mix of policies; however, they have also created opportunities for creative ways of reorganization in various areas, including those related to resource management (De Lopez 2001). Government institutions, such as the Department of Fisheries, have typically controlled resources centrally. However, given the technical and budget constraints that such institutions face, there is a growing awareness that other forms of management, including participatory ones, may be feasible. This has created space for experimentation in many arenas.

Experiments with resource management, perhaps fuelled by declining access to natural resources and a pervasive donor culture, have led to the emergence of community-based approaches in the area of fisheries and forestry. Although approaches vary, communities are actively establishing their own management areas and plans, often with support from non-governmental organizations (NGOs) or government institutions. Community-based approaches have been proliferating. For example, in 2002 there were an estimated 162 community fishery sites and 237 community forestry sites in Cambodia (McKenney and Prom 2002). Such a proliferation requires extensive capacity and institution building, and there has indeed been some policy development in support of community-based management. For example, a community forestry sub-decree was passed in 2003 and a community fisheries sub-decree has been drafted and is under review as of 2003. However, policies tend to be disjointed and support is inadequate because the initiatives are undertaken without a real understanding of what community management entails.

Community-based management approaches in Cambodia share certain characteristics. These include emphasis on the promulgation of rules and regulations; formation of resource management committees to guide community-based management initiatives; thumb printing villagers who support such work; establishment of demarcated areas for management; and collecting official signatures from the commune, district and provincial or national level, as appropriate. Although the structures on paper regarding management plans and approval mechanisms are similar, experience shows that what is happening 'on the ground' may be quite different in different areas - even between different sites in the same area. The official status of a committee appears to be neither a necessary nor a sufficient condition for its effectiveness. For instance, some resource management committees, although recognized by an appropriate government institution, remain inactive, whereas community-based management is active in some villages, even in the absence of formal organizations or official recognition.

Many of the community forestry and fishery sites in Cambodia have an elected resource management committee (also known as a community fisheries or forestry committee) that is responsible for guiding resource management activities. However, none of these committees has any official power. There are government policies for supporting community management, but (as of 2003) limited legislated community rights for local resource management. Composition and operations of these committees vary, as illustrated by the two committees discussed in this paper. In Koh Sralao, prior to holding a committee election, villagers developed and accepted rules and regulations pertaining to resource management. Villagers 
then elected a committee of seven people, including two women, to oversee resource management activities. The committee holds monthly meetings, but additional meetings may be held when problems arise.

In Kompong Phluk, the resource management committee was elected after several meetings, and then worked together to make the rules and regulations. This committee consists of nine representatives (including two women) from the three villages that form the commune. In 2001, the fishing area under Kompong Phluk's management increased 15-fold. Prior to 2001, most of the Tonle Sap fishery (where Kompong Phluk villagers fish) was managed by individual contractors (leased from the Department of Fisheries) in blocks of areas known as fishing lots. Communities and small-scale fishers had little access to much of the fishery. In 2001, however, $56 \%$ of fishing lot areas in Tonle Sap were released to communities for local management (Evans 2002). This rapid policy shift, done as part of a decentralization mandate, happened without a plan to provide technical support to communities. To accommodate this change, the resource management committee of Kompong Phluk expanded, in numbers and mandate, and roles and responsibilities were updated. The Kompong Phluk resource management committee (in contrast to Koh Sralao) holds meetings whenever something needs to be discussed or when problems arise.

Table 2 highlights key characteristics of the resource management committees in Koh Sralao and Kompong Phluk, including: why the committees were established; their legal status; resource management issues addressed; examples of strategies for addressing issues; and reasons for villager support for the resource management committee in their village or commune. Although both committees are relatively young, having been established in 1999 and 2000 respectively, both have been able to experiment with various resource management strategies. For example, in Koh Sralao initial resource management practices emphasized environmental education and patrolling to prevent illegal activities, such as trawling and dynamite fishing, theft of fishing gear and charcoal production. Over time, however, the resource management committee decided to enhance this work through facilitating conflict resolution mechanisms in an attempt to find solutions in which more villagers could engage and which could be implemented without donor support. One such mechanism, which will be expanded upon later, addresses conflicts over stolen fishing gear.

Although both resource management committees were initially formed to address communitybased resource management issues, they view their mandate more broadly. For example, in Koh Sralao the resource management committee is finding solutions to other community problems, such as supporting young schoolteachers to stay in their village. In Kompong Phluk, the resource management committee helps poor families in times of need, for example by providing support for funeral ceremonies. In each village, resource management committee members suggested that villagers support their work mainly because committees have been able to build trust to get things done. Villagers believe that their livelihoods are improving as a result of this work and the leadership of the committee leaders.

Resource management committees may be active without endorsement from local officials. However, experience in both field sites suggests that having support for community-based management from officials at the commune level helps to facilitate support for such work. For example, in Koh Sralao the resource management committee leader is also a member of the Commune Council (which became an elected body for the first time in 2002). As a result, there is a strong environmental mandate within this Commune Council's five-year plan. In Kompong Phluk, a member from the Commune Council acts in an advisory role to the resource management committee, thereby being able to link environmental issues with broader local governance issues.

While having informal or formal policy support is important, the committee's experience suggests that it also requires motivation and problemsolving skills from the resource management committees themselves to drive the work. For instance, in both Koh Sralao and in Kompong Phluk, multiple strategies are used for dealing with illegal activities and resource declines. The strategies include creating local systems of support; getting police and government agencies to engage in patrolling and enforcement activities together with villagers; disseminating rules and regulations; and networking amongst villagers to support the committee's work. 
Table 2 An overview of two resource management committees

\begin{tabular}{|c|c|c|}
\hline & Koh Sralao & Kompong Phluk \\
\hline $\begin{array}{l}\text { Why committee } \\
\text { was formed }\end{array}$ & $\begin{array}{l}\text { Established in 2000, after working with an } \\
\text { NGO for several years and seeing dramatic } \\
\text { resource declines (fishery and mangroves) in } \\
\text { their area. Although an in-migrant } \\
\text { community, with people initially being lured } \\
\text { for resource extraction opportunities, a need } \\
\text { for resource management is seen by some. }\end{array}$ & $\begin{array}{l}\text { Established in 1999, with support from an } \\
\text { NGO. History of resource management, } \\
\text { specifically flooded forest protection. } \\
\text { Community members wanted to strengthen } \\
\text { their resource management practices and get } \\
\text { help in dealing with farmland encroachment. }\end{array}$ \\
\hline Legal status & $\begin{array}{l}\text { Informal - supported by agreements (maps } \\
\text { of community management area, rules and } \\
\text { regulations) with Provincial Governor and } \\
\text { Minister of Environment (village is within a } \\
\text { protected area). }\end{array}$ & $\begin{array}{l}\text { Informal - supported by agreements (maps of } \\
\text { community management area, rules and } \\
\text { regulations) with Provincial Governor. }\end{array}$ \\
\hline $\begin{array}{l}\text { Management } \\
\text { issues addressed }\end{array}$ & $\begin{array}{l}\text { Illegal fishing, both inside and outside their } \\
\text { community; charcoal production; stealing of } \\
\text { fishing gear; declining resources; waste } \\
\text { management; and other community issues. }\end{array}$ & $\begin{array}{l}\text { Flooded forest cutting; illegal fishing, both } \\
\text { inside and outside their community; } \\
\text { declining resources; farmland encroachment; } \\
\text { and other community issues. }\end{array}$ \\
\hline $\begin{array}{l}\text { Examples of } \\
\text { management } \\
\text { strategies }\end{array}$ & $\begin{array}{l}\text { Solving theft through innovative solutions } \\
\text { (painting crab traps, patrolling); supporting } \\
\text { local schoolteachers. }\end{array}$ & $\begin{array}{l}\text { Engaging community members in a local } \\
\text { system of forest protection; supporting poor } \\
\text { villagers in times of need (funerals). }\end{array}$ \\
\hline $\begin{array}{l}\text { Reasons for } \\
\text { villagers' support }\end{array}$ & $\begin{array}{l}\text { Key community members are involved in the } \\
\text { committee; people believe there are more } \\
\text { mangroves and crabs as a result of this work; } \\
\text { village leaders openly support committee, } \\
\text { delegating responsibilities to it. }\end{array}$ & $\begin{array}{l}\text { Villagers believe in/trust the work of the } \\
\text { committee; small commune, easy to } \\
\text { communicate; people are long-term } \\
\text { residents, so much local wisdom; people } \\
\text { believe there is less farmland encroachment } \\
\text { as a result of this work. }\end{array}$ \\
\hline
\end{tabular}

\section{WHY PARTICIPATE IN COMMUNITY-BASED MANAGEMENT?}

Villagers may choose to participate in communitybased management initiatives for a number of reasons, which are often overlapping and difficult to tease apart since villagers view their resources holistically (i.e. they see fishery and forestry issues as linked). Nonetheless, it appears that the reasons for participation may include spiritual aspects, e.g. to protect forests near pagodas. The reasons may be political, e.g. for personal benefit or prestige, or historical, i.e. there may be a tradition of resource management in the village. They may be environmental, e.g. to stop or slow down rampant resource declines, or economic, i.e. the belief that protection can lead to income generation for community development. The reasons may also involve relationship building, e.g. the donor can help facilitate or negotiate requests on behalf of the village.

To investigate more specifically what motivates villagers to invest their time and effort in community-based management, we discussed with villagers their notions of future and sustainability. Two questions were posed, one regarding the future, worded in terms of their children's future, and the other as local definitions of sustainability.

In this discussion, villagers linked communitybased management with sustainable livelihood practices. One villager commented that, 'if we protect our flooded forest [forest area that is submerged or partially submerged seasonally] and do not take the small fish, our children will be able to support their families.' However, when villagers were asked about what was important for their children's future, most expressed the need for access to higher education or for their children to have options other than fishing. While villagers recognized the importance of resource protection and sustaining livelihood activities, a variety of livelihood activities, including the ability to gain employment outside the village, were also emphasized. Community-based management, therefore, 
was seen as something that could benefit some community members in terms of enhanced livelihoods. This, in turn, might lead to future opportunities either inside or outside the village.

There is no direct translation of the word sustainability into Khmer. Villagers, after lengthy discussions linking their children's future with local resources, defined sustainability as 'all things living for a very long time' and 'prosperity for children and for village development'. Having established that there were, in fact, local concepts of the future and sustainability - and that they were considered important in the context of villagers' children and future livelihood options - we turned to discussions with village management committees. In Kompong Phluk, villagers engage in resource protection for historical reasons and as a response to environmental decline and access to resources, specifically farmland encroachment in their community forest.

Long before the fisheries community was set up, people loved and took care of the forest. It was not perfectly managed, though, especially in recent times. So, it was good timing to work with [NGO], for them to help us. We wanted to stop the mung bean farming near our commune and needed outside support (an elder, pers. comm., Kompong Phluk 2003).

For this Elder, having lived in Kompong Phluk all his/her life, flooded forest protection made sense as there was a history of resource management in Kompong Phluk. Elders recall protesting against watermelon farms encroaching their village area in the 1940s and stopping further loss of forest (Poffenberger 2002).

The experience in Koh Sralao has been quite different from Kompong Phluk. Most villagers migrated to Koh Sralao after the Khmer Rouge era with the hope of cashing in on lucrative resource extraction opportunities. Resources remained relatively abundant until the $1990 \mathrm{~s}$, but rapid resource declines since have greatly affected local livelihoods, thereby motivating villagers to "do something'. We discuss elsewhere the experience in the Koh Sralao area of one project team mobilizing villagers around the issue of mangrove decline and how the use of this experience for adaptive co-management can be applied more generally (Marschke and Nong 2003).
This is not to suggest that all villagers in the two communities are active in supporting the work of the resource management committees; participation does remain an issue. Multiple factors can affect who is active in a community. For example, family responsibilities can make it difficult to participate, and hence women have less opportunity to do so. In other cases, villagers who have difficulty meeting basic needs cannot afford to volunteer their time towards resource management or other community activities. Consider the comment of one former resource management committee member:

Right now my livelihood situation is not very good. I need to focus on my family first. When I find a job with a secure income and finish building a house for my family then I can return to working with the resource management committee. It takes up a lot of time, and I am too worried about my family right now (a crab fisher, pers. comm., Koh Sralao 2003).

Households do not necessarily have the choice of active participation, and therefore management committee members tend to be villagers who have decent livelihoods and are influential. Often, these people have strong social networks and relationships that they can call upon to support their work.

\section{COMMITTEE RESOURCE MANAGEMENT STRATEGIES}

Since our commune is small, we work easily together. Each village is responsible for protecting one part of the forest and we are all responsible for protecting the forest near the village (a Village Management Committee member and fisher, pers comm., Kompong Phluk 2003).

The resource management committee in Kompong Phluk knows that the forest near their commune protects them from wind and storms. Issues that the committee addresses include: (a) forest protection; (b) illegal fishing activities; (c) resource decline; (d) farmland encroachment; and (e) other community activities. Multiple strategies are used to tackle these issues, some of which are working better than others. For example, while patrolling activities may seem to be the obvious solution to stopping illegal activities near the community, patrolling is expensive because of fuel costs 
and because the community cannot generate enough income to support consistent patrols. Patrolling is also risky as it can escalate into conflict and is difficult to organize for the lack of consistent technical support. Although resource management committee members do engage in patrolling activities with police and technical staff, they also focus on networking inside and outside the village, to strengthen their own practices and that of neighbouring communes and districts. As elsewhere in the world, peer pressure can work wonders regarding compliance (Ostrom 1990; Bingeman et al. 2003)! Table 3 highlights some of the issues and the strategies devised by the resource management committee to resolve these issues.

Many small-scale Cambodian fishers face the common problem of declining resources and stolen fishing gear. Stolen or destroyed gear leads to conflict, both among villagers, and with those using the same fishing grounds. In Koh Sralao, for example, crab traps were constantly being stolen, mostly by outside fishers but sometimes by villagers themselves. After several brainstorming sessions, the resource management committee decided to devise a system to enable villagers to recognize their own crab traps more easily:

After many discussions we had an idea. Each group [of the eight that the village is divided into] has to mark their crab traps with the same colour. Individual owners then, using this colour, have a specific sign i.e. slash marks in certain directions indicates whose traps these are. So far, painting the crab traps has been a good solution for cutting down the stealing of crab traps. People that are caught with the wrong colour traps are fined. Or, they are asked to give back new traps. We cannot solve all the problems, but this is helping (pers. comm., Koh Sralao 2003).

In general, villagers were happy with this solution. One fisher commented, 'I have had less traps stolen than last year. I now can sleep in the village at night, and am not afraid to leave my traps.' This solution is providing some security for fishers, and villagers are working together to watch for boats that they do not recognize. Although crab traps do continue to be stolen, villagers thought that there was a decrease in theft and a better chance of recovery of stolen crab traps.

Another management strategy, both in Kompong Phluk and in Koh Sralao, was the creation of fish sanctuaries within community management boundaries. In the case of Koh Sralao, some fishers developed the technique of using hand pushnets (a kind of beach seine) to catch live grouper (Epinephelus spp.) fingerlings for the Thai market. As more fishers got into the fishery, too much pressure developed on the inshore sea-grass beds in which groupers were found. Faced with imminent depletion, the village resource management committee, with PMMR facilitation, established a demarcated no-fishing area to protect the core of the grouper nursery area.

As one fisher noted, 'our fish sanctuary is located near our fishing grounds so it is easier for us to protect this area. Plenty of fish can now be found there, and this makes us realize that we need more areas

Table 3 Resource management strategies in Kompong Phluk

\begin{tabular}{|c|c|}
\hline Management issue & Management strategy \\
\hline Flooded forest cutting & $\begin{array}{l}\text { Committee directs villagers } \\
\text { to manage specific parts of } \\
\text { the forest, reporting any } \\
\text { illegal activities to the } \\
\text { committee, which then } \\
\text { investigates and tries to solve } \\
\text { the issue (if possible). }\end{array}$ \\
\hline $\begin{array}{l}\text { Use of illegal fishing } \\
\text { gear (push nets, electro } \\
\text { fishing, long bamboo } \\
\text { traps) and theft }\end{array}$ & $\begin{array}{l}\text { Patrolling and fining for } \\
\text { illegal gear; discussions with } \\
\text { other communes about } \\
\text { Kompong Phluks' rules and } \\
\text { regulations; community } \\
\text { members working closely } \\
\text { with committee to stop illegal } \\
\text { activities and to monitor } \\
\text { their own fishing practices. }\end{array}$ \\
\hline Declining resources & $\begin{array}{l}\text { Creation of a } 1 \mathrm{~km}^{2} \text { fish } \\
\text { sanctuary; educating people } \\
\text { about the rules of the } \\
\text { community; villagers } \\
\text { encouraged to collect } \\
\text { floating wood for firewood } \\
\text { and to collect fuel wood } \\
\text { outside of mature-forest } \\
\text { areas. }\end{array}$ \\
\hline $\begin{array}{l}\text { Farmland } \\
\text { encroachment }\end{array}$ & $\begin{array}{l}\text { Work with provincial } \\
\text { authorities and NGO staff to } \\
\text { stabilize encroachment. }\end{array}$ \\
\hline Other activities & $\begin{array}{l}\text { Supporting poor villagers in } \\
\text { times of need }\end{array}$ \\
\hline
\end{tabular}


where we protect fish.' Fishers themselves, along with local authorities, can monitor the no-fishing zone. Of course, if large-scale fishers from the outside, such as trawlers, decide to not respect local rules, greater technical/outside support would be needed. The resource management committees recognize that they cannot resolve all problems, but with creative thinking some issues can be addressed to work towards the sustainability of their livelihoods, resource base and communities.

\section{STRUGGLING WITH SUSTAINABILITY}

Finding solutions to complex issues takes time and often involves multiple stakeholders, both within and outside a community. Moreover, implementing strategies that are locally accepted, viable and can enhance livelihood sustainability is challenging. The experience of both resource management committees illustrates that committee members deliberate and experiment with different strategies and ideas in their attempt to enhance local livelihoods.

The resource management committee in Koh Sralao, for example, has been grappling with how to prevent the rapid decline of one of its main livelihood resources, the swimming crab, Portunus spp. Three-quarters of all fishers in Koh Sralao use crab traps with 2-cm mesh size to land crabs that, according to provincial biologists, are too small and are pre-reproductive. Fishers themselves have commented on how this species has steadily decreased in size, especially in the last five years (this is in contrast to the two species of mud crab, Scylla spp., which fishers believe have increased with mangrove habitat protection). The risk of catching such small swimming crabs is the reproductive stock is reduced, leading to population collapse.

Cambodia's 1987 fisheries law requires $10-\mathrm{cm}$ mesh size be used for crab traps, an unrealistic rule given the size of crabs in the area. Internal regulations in Koh Sralao, voted upon by all villagers, require 4-cm mesh size. However, when it came to implementing this regulation, villagers resisted:

Although everyone in the village agreed to this [4-cm mesh size], when it came time to implement this regulation fishers reacted, stating that they would lose personal benefits [grouper by-catch] if they increased their mesh size. We [resource management committee] met together, and decided to ask fishers to increase their mesh size a little, from $2 \mathrm{~cm}$ to $3 \mathrm{~cm}$. Fishers felt alright about this idea. Between $60 \%$ and $70 \%$ of fishers switched to 3-cm mesh size by late 2002 (pers. comm., Koh Sralao 2003).

Koh Sralao fishers, however, became disheartened and frustrated when they realized that outsiders using their fishing grounds were not following their community regulations. 'It is not fair that I increase my mesh size to allow the crabs to grow but outsiders continue to use a smaller mesh size, thereby getting all the benefit,' noted one fisher. Thus, fishers returned to a 2-cm mesh size after only one season. In this case, a community-level solution was found. However, changing mesh size did not work out the way it was envisioned, for several reasons: (a) villagers could not control, or regulate, who entered their demarcated fishing grounds and (b) the crab stock migrates over many fishing grounds. In the case of shared commons, resource management cannot work with the compliance of one village alone (Ostrom 1990; Berkes et al. 2001). A committee member noted:

In Koh Sralao we have to find one strategy to reach new fishers who do not understand the resource and another strategy to reach those that only want to exploit the resources. Also, we have to find a way to convince both local authorities and technical authorities to provide us with more support. Sometimes we do not have the power to do all this (pers. comm., Koh Sralao 2003).

This committee, with support from PMMR, has worked with neighbouring villages to negotiate mesh sizes used for crab traps. Although all stakeholders agree that mesh sizes should increase, no additional communities have implemented this regulation. However, unless everyone implements such a strategy, there is little hope that the swimming crabs can be successfully sustained. This case highlights how difficult it is to address the overfishing of stocks that are mobile and seasonal (Berkes et al. 2001). Perhaps the current crisis in the swimming crab fishery will lead to negotiated, incremental solutions, or alternatively a stock collapse will force a closure of the fishery. Either way, Koh Sralao's resource management 
committee is well situated to deal with the crisis because they will be able to apply their learning from previous crisis (Marschke and Nong 2003).

Turning to the second study site, Tonle Sap Lake fisheries are organized through a community fishing ground allotment system that covers the seasonally flooded lake margin. Individual communities or clusters of communities (communes) have access to the flood plain fishery through this arrangement (Evans 2002). As already mentioned, under the 2001 fisheries policy reform, some of the Tonle Sap area communities have been allocated extra fishing grounds. In the case of Kompong Phluk, the additional fishing area allocated is very substantial: on paper, Kompong Phluk has had a 15-fold increase in community fishing grounds in 2001.

However, Tonle Sap is a large, heavily fished lake. The open waters of the lake are used by large-scale fishing operations, and the community fisheries of Kompong Phluk are unable to control the fishing ground that they have been allocated. Hence, the resource management committee is struggling with how to enhance livelihood options for community members now that their fishing grounds have increased. 'We are not catching more fish even though we have access to a much larger fishing area,' noted one committee member. 'Big fishers continue to use most of this area, and it is difficult for us to stop them.' Although conflicts near the community are often resolved, it remains difficult for the resource management committee to enforce fisheries management within the expanded community fishing area.

We conducted a brainstorming session with the Kompong Phluk resource management committee to examine alternative solutions to the enforcement problem and if some of these may be viable in their opinion. Their responses to the options were indicative of extensive community discussions on planning and action, and an understanding of the management and legal context of the situation. Brainstorming was conducted around four alternative solutions or options.

Given that the community was unable to harvest its allocated fishing ground fully and control the larger fishers, were there ways to make deals with some of these fishers? Would a joint venture option, enabling community members to sell their rights to outsiders, work? The committee mulled over this idea and eventually rejected it for two reasons. First, they did not think that their resource rights were strong or secure enough to sell or rent, as in transferable fishery quotas found in some countries. Second, if they invited a large fisher into their community area, it might be even more difficult to get rid of her/him later. Such 'a person might over-fish, even if we had strong rules. We cannot prevent large fishers from cleaning out an area, even if we had an agreement.'

A second option followed the practice in some Philippines lagoon fisheries in which armed guards are used to protect valuable fishing grounds. How would you feel about giving community members guns to patrol the area? This option was not seen as viable or desirable, given the recent experience in Cambodia with the Khmer Rouge. A committee member commented that 'violence does not solve problems, and besides, a larger fisher is likely to have a bigger gun than the community patrol.' Another committee member commented, 'if the illegal person has a gun, which is often the case, then there would be violence. Actually, this is not a good idea because we do not want more violence in our area.'

A third option was to use the power of the temple, blessing the fishing grounds through a seasonal ceremony, as done in some community fisheries (such as in Brazil) and discouraging potential poachers through religious sanctions. What about using Buddhist teachings to stop illegal practices? This idea received considerable discussion and many smiles but, ultimately, it was not seen as plausible:

This cannot work. Every fisher kills fish, and this already goes against Buddhist teachings. We already have a problem, according to Buddhist teachings, since killing an animal is considered bad karma. We don't have the moral authority to use religious teachings to improve our resource management practices' (pers. comm., Kompong Phluk 2003).

A fourth option may be to compete with the large fishers on their own terms by using the kinds of highly efficient nets that large fishers employ. 'If we use illegal gear, then we cannot expect the authorities to help us,' commented one member. 'Institutions need to respect the law, and that includes us. Right now they close their eyes, so the only option is for each institution to begin respecting the law.' As well, committee members noted 
that small fishers gearing up to become more like the big fishers would violate the basic principles under which Cambodia has been implementing community fisheries.

The Kompong Phluk discussion highlights the multiple factors that resource management committees actually do consider when working towards resource sustainability. Both cases show the sophistication with which committees have been assessing conflict management, resource sustainability, the legal and even the ethical background of the fishery. The cases illustrate how equity and livelihood considerations bring out the question of power and access rights (Sachs 2002). Ironically, fishers themselves are encouraged, through informal policies, to become resource managers - but without being given the technical or financial resources to manage the fishery or to enforce regulations. Indeed, the willingness of local community members to engage in resource management is impressive in itself, considering the barriers they face.

\section{DISCUSSION}

Since the end of the intense era of political turmoil, Cambodia has been in a state of reorganization, providing a window of opportunity for sustainability planning. In resource management, a key platform of this planning has been communitybased management. In Cambodia, experimentation with community-based fisheries and forestry initiatives has begun, in part encouraged by donor agencies favouring participatory, democratic approaches, as seen in other parts of the world as well (Moffat et al. 1998). But it is in part motivated by a real search for alternatives to reverse resource declines, one could say, starting with a perception of unsustainability (Wilkinson and Cary 2002). The larger sociopolitical context is that communitybased management is being used as a tool to provide some measure of environmental security in the aftermath of the Khmer Rouge regime and the resulting relocations.

How do Cambodian villagers perceive sustainability and what do they do 'on the ground'? Research undertaken with two local-level resource management committees highlights how community-based management can evolve over a period of time in response to concerns about forests, fishing areas and other village-level problems. Looking at sustainability issues through the lens of resource management committees, community-based management is particularly significant when it is seen to be enhancing livelihoods. Villagers are most willing to engage in community-based management when they believe that they can improve livelihoods within their community. For example, the establishment of a fish sanctuary in grouper nursery areas by the Koh Sralao resource management committee is illustrative of evolving sustainability thinking. A few years ago, grouper fingerlings would have been fished hard as long as a market existed for them because there was no individual incentive to conserve - what one fisher left behind today would have been harvested by another. The development of community-based management made it possible to consider longer-term sustainability issues. Tangible results from the work of village management committees are many and include fewer stolen crab traps and reduced social conflict, denser forests and less farmland encroachment, mangrove recovery, and increased cooperation among villagers.

We know that the resource management committee will help us. They have taught us about mangrove replanting and about protecting our resources. There are more crabs this year near the mangroves, and we understand the relationship between mangroves and a healthier fishery (a fisher, pers. comm., Koh Sralao 2003).

'Community-based resource management' puts the emphasis at the local level, but most (if not all) resource management systems have cross-scale linkages and external drivers at various scales (Berkes 2002). Political relocations, a pervasive donor culture, economic imperatives and market demands are some of the driving forces not explored in detail here. Instead, we focus on cross-scale linkages as illustrated by the experience of the two resource management committees. We briefly comment on three aspects of cross-scale linkages: local-level administrative support and leadership, the flexibility of the current arrangement, and the significance of new legislation for community-based management.

The two local resource management committees considered here were not picked at random; in Cambodia most of these committees exist on paper only. One of the reasons for the effectiveness of the committees in Kompong Phluk and Koh Sralao 
is support from Provincial Governors, whose endorsement facilitates the support of the Commune Council. Without the endorsement of management plans from the commune, the committees most likely could not function as well. While the NGOs working in both areas have helped to secure support at various scales (especially provincial and national level), the committees are effective at a village level because of local leadership. Leadership, including the willingness to take risks, is critical to garnering support of the local community. In our cases, both resource management committee leaders are respected within their village and tend to be influential in the community.

Flexibility is another factor of success. Resource management committees have had the flexibility (such flexibility has, no doubt, been encouraged by the NGOs) to address issues as they have arisen in the community. Neither committee is strictly bound by a rigid mandate, recognizing that they have the ability to solve problems around different community issues, whether these be environmental or social. For example, upon request of the resource management committee in May 2003, Koh Sralao villagers hauled cement and other materials up a steep hill for the construction of a pagoda hall, used as a meeting place for different community events. Resource management, in a way, is a vehicle for committees to address and deal with a range of community-level issues.

New legislation being drafted (and in the case of the community forestry, sub-decree, passed) for community-based management in Cambodia has the potential to reduce this flexibility by making mandates more rigid, but of course it also carries the promise of enabling and strengthening locallevel management. A critical question is how policy can best be implemented to serve sustainability, equity and livelihood objectives (Sachs 2002).

Our analysis indicates that villagers' view of sustainability is holistic and not sectoral; people see the connections between lands and waters and mangroves and crabs. Hence, some critical thought is needed to assess how different community-based policies identified in a range of legislation and programmes (e.g. community fisheries sub-decree, community forestry sub-decree, protected areas law, land law, local governance programmes, etc.) can best support sustainability needs, rather than leading to fragmentation.

As has been shown by the experience in Kompong Phluk and Koh Sralao, communitybased management can emerge in many ways. Through self-organization and development of common institutions, experimentation, elaboration of knowledge and social learning, unsustainable practices can be made more sustainable. In this regard, the development of the ability to selforganize, learn and adapt, may be more important than solving particular problems (Berkes et al. 2003). Creating the political space for communities to practice learning-by-doing, and enabling communities to deal with resource management problems can be effective ways to facilitate the dynamics of sustainability 'on the ground'. Finding and sustaining flexible approaches that support creative learning-by-doing and problem-solving opportunities represents an important challenge for local resource management and development.

\section{ACKNOWLEDGEMENTS}

We would like to thank Kim Nong, Patrick Evans, Khy An and Dyna Eam for their tremendous insights and support in conducting this research, along with the resource management committees of Koh Sralao and Kompong Phluk. We also thank Dr. Gary Newkirk and Bruce McKenney who commented on various drafts of this paper. Marschke's research was supported by the International Development Research Center (IDRC) and the Social Sciences and Humanities Research Council of Canada (SSHRC). Berkes' work was supported by the SSHRC and the CRC program.

\section{REFERENCES}

Adams WM. Green Development: Environment and sustainability in the Third World. 2nd edn. London: Routledge; 2001

Berkes F, Colding J and Folke C (eds). Navigating the Dynamics of Social-Ecological Systems. London: Cambridge University Press; 2003 
Berkes F. Cross-Scale Institutional Linkages: Perspectives from the bottom up. In Ostrom E, Dietz T, Dosak N, Stern PC, Stonich S and Weber EU (eds), The Drama of the Commons. Washington, DC: National Academy Press; 2002:293-321

Berkes F, Mahon R, McConney P, Pollnac R and Pomeroy R. Managing Small-Scale Fisheries: Alternative Directions and Methods. Ottawa: International Development Research Centre; 2001

Bingeman K, Berkes F and Gardner JS. Institutional Responses to Development Pressures: resilience of social-ecological systems in Himachal Pradesh, India. International Journal of Sustainable Development and World Ecology 2004;11:99-115

Blaikie P. Understanding Environmental Issues. In Morse S and Stocking M (eds), People and the Environment. London: UCLA Press; 1995:1-30

Chambers R. Whose Reality Counts: putting the first last. Bath: Bath Press; 1997

Chambers R and Conway G. Sustainable Rural Livelihoods: practical concepts for the 21st century. Institute of Development Studies Discussion Paper 296. Brighton: Institute of Development Studies; 1992

De Lopez T. Deforestation in Cambodia: a stakeholder management approach. International Journal of Sustainable Development and World Ecology 2001;8:380-94

Ekstrand L and Ray R. Chaos and Complexity in Development. International Journal for Sustainable Development and World Ecology 2001;8:127-36

Evans P. Fishing Disarmed, Community Fisheries in Cambodia. Samudra 2002; March: 6-12

Godfrey M, Sophal C, Kato T, Piseth L, Dorina P, Savora $\mathrm{T}$ and Sovannarith S. Technical Assistance and Capacity Development in an Aid-dependent Economy: the experience of Cambodia. World Development 2002;30(3):355-73

Holling CS (ed). Adaptive Environmental Assessment and Management. London: Wiley; 1978

IIRR. Participatory Methods in Community-based Coastal Resource Management, 3 vols. International Institute of Rural Reconstruction, Silang, Cavite, Philippines; 1998

Kates RW, Clark WC, Corell R, Jaeger IL, McCarthy JJ, Schellnhuber H, Bolin B, Dickson NM, Faucheax S, Gallopin GC, Gruebler A, Huntley B, Jager J, Jodha NS, Kasperson RE, Mabogunje A, Matson P, Mooney H, Morre B, O'Riordan T and Svedin U. Sustainability Science. Science 2001;292:641-2. Statement of the Friibergh Workshop on Sustainability Science. Available from the Internet: http://sustsci.harvard.edu/keydocs/friibergh.htm

LaRochelle $\mathrm{S}$ and Berkes F. Traditional ecological knowledge and practice for edible wild plants: biodiversity use in the Raramuri in the Sierra Tarahumara, Mexico. International Journal of Sustainable Development and World Ecology 2003; 10:361-75

Lee KN. Compass and Gyroscope: integrating science and politics for the environment. Washington DC: Island Press; 1993

Ludwig D, Hilborn R and Walters C. Uncertainty, Resource Exploitation and Conservation: lessons from history. Science 1993;260:17, 36

Marschke M and Nong K. Adaptive Co-management: lessons from coastal Cambodia. Canadian Journal of Development Studies 2003;24(3):369-83

McKenney B and Prom T. Natural Resources and Rural Livelihoods in Cambodia: A baseline assessment, Working Paper No. 23. Phnom Penh: Cambodia Development Resource Institute; 2002

Moffat D, Ngolle MN, Linden O and Francis J. The Reality of the Stomach: coastal management at the local level in eastern Africa. Ambio 1998;27 (8): $590-8$

Olsson P, Folke C and Berkes F. Adaptive CoManagement for Building Resilience in SocialEcological Systems. Environmental Management 2004;34(1):75-90

Olsson P and Folke C. Local Ecological Knowledge and Institutional Dynamics for Ecosystem Management: a study of Lake Racken watershed, Sweden. Ecosystems 2001;4:85-104

Ostrom E. Governing the Commons: The Evolution of Institutions for Collective Action. Cambridge: Cambridge University Press; 1990

Poffenberger M. Transitions to Community Resource Management around the Great Lake, Tonle Sap, Cambodia, Draft case study. Siem Reap, Cambodia: Participatory Natural Resource Management in the Tonle Sap Region and the Community Forest Management Support Program for Southeast Asia; 2002

Pomeroy B and Berkes F. Two to Tango: the role of government in fisheries management. Marine Policy 1997;21(5):465-80

Sachs W. Fairness in a Fragile World: the Johannesburg agenda. Development 2002;45(3): 12-17

Scoones I. Sustainable Rural Livelihoods: a framework for analysis. IDS Working Paper 72. Brighton: Institute of Development Studies; 1998

Sneddon C. Sustainability' in Ecological Economics, Ecology and Livelihoods: a review. Progress in Human Geography 2000;24(4):521-49

Wilkinson R and Cary J. Sustainability as an Evolutionary Process. International Journal of Sustainable Development and World Ecology 2002;5(4): 381-91 